\title{
The Use of Social Media for Communication and Education in Debre Tabor University, Ethiopia
}

\author{
Destaw Bayable Yemer \\ Researcher and Lecturer, Guna Tana Integrated Field research and Development Center, Debre Tabor \\ University, Debre Tabor, Ethiopia \\ Dessalegn Yeshambel Wassie \\ Lecturer, Debre Markos University, Department of Journalism and Communication, \\ Debre Markos, Ethiopia
}

\begin{abstract}
The purpose of this study was to examine the use of social media in Debre Tabor University (DTU) undergraduate students that how they use social media for communication and education with connected to MacQuails (1983) theoretical framework of why do people use media and what do they use them for? In this study, 285 questionnaires were distributed to DTU undergraduate students so as to assess their personal usages of social media for communication and education. The researchers employed mixed research method. The data was gathered through survey questionnaires which consisted quantitative and qualitative questions. Accordingly, the findings indicated that all of the respondents use online social networks and they have one form of social media profiles. They use it through their smartphone with moderate and enough technology use and attitude. It also revealed that $75 \%$ of respondents use social media for communication, resource sharing and collaboration. They use it, to communicate with web-community, to build their social capital. Nevertheless, the use of social media for education in DTU was very poor almost not an iota in formal ways. The respondents have interests to use social media for education as for problem solving, individual learning, discussion, research, guided discovery, and collaborative work, case studies and demonstration respectively. The researchers recommend that social media is useful tool for university community due to its low cost, immediacy, accessibility, and its heterogeneous audience. Thus, students should use social media for communication and education.
\end{abstract}

Keywords: Social Media, Social Networking, Communication, Education, Use and gratification, Debre Tabor University

DOI: $10.7176 / \mathrm{NMMC} / 87-02$

Publication date: January $31^{\text {st }} 2020$

\section{INTRODUCTION}

\section{Background of the Study}

Social media is "a group of internet-based applications that build on the ideological foundations of Web 2.0, and that allow the creation and exchange of User Generated Content" Kaplan and Haenlin (2010). They add that all social media fall into six different categories: collaborative projects, blogs, content communities, social networking sites, virtual social worlds, and virtual game worlds. This classification assists in understanding the uses of a given social media platforms. Social media provides greater control in communication over both the degree of privacy and size of group (Ibid).

Fred Cavazza (2008) also breaks down the various forms of social media into ten categories in his "Social Media Landscape": publication tools, sharing tools, discussion tools, social networks, micro-publication tools, social aggregation tools, live-cast, virtual worlds, social gaming and massively multiplayer online gaming.

Moreover, Boyd and Ellison (2008) also defined social network sites as public web-based services that allow users to develop a personal profile, identify other users ("friends") with whom they have a connection, read and react to postings made by other users on the site, and send and receive messages either privately or publicly. Individuals may choose to send private messages, write on other user's walls, organize social activities, and keep informed about other user's daily activities. This is not the only, it helps the users to create a user profile, add other users as "friends" exchange messages, make comments, post status updates and photos, share videos and receive notifications when others update their profiles. However, in social networks users can limit themselves on what information they would like to share publicly with others. Some items they may choose to include are: pictures, favorite books and movies, birthday, relationship status, location status and music Tufekci (2008).

Social media have the capabilities of technology that provide interactive platforms for the public to share, create, discuss, and modify content. As Neil Selwyn (2012) described social media in terms of collaboration, conviviality, and creativity. Besides of these, social media usage has been found to have increased all over the world which is in the so-called developing countries.

According to Solis (2008), social media comprises of activities that involve socializing and networking online through words, pictures, and videos. Social media is redefining how we relate to each other as humans and how 
we as humans relate to the organizations that serve us. It is about dialog; two way discussions bringing people together to discover and share information. It helps the users communicate horizontally freely.

Social media networks have created a phenomenon on the internet that has gained popularity over the last decade. People use social media sites such as Facebook, Twitter, and Myspace to create and sustain relationships with others (Boyd \& Ellison, 2007). These social media sites let those who use them create personal profiles, while connecting with other users of the sites. Users can upload photographs, post what they are doing at any given time, and send personal or public messages to whomever they choose. In this "information age," social media sites seem to be growing in popularity rapidly, especially among young adults (Pempek, Yermolayeva, \& Calvert, 2009).

Accordingly, social networking is one aspect of social media, where individuals are in communities that share ideas, interests, or are looking to meet people with similar ideas and interests. Social media have vital role for communication and education in higher education to build social capital, share resources and collaboration. Social media here serve as social utility that connects people with friends and others who work, study and live around them. People use social media to keep up with friends, upload and set an unlimited number of photos, share links and videos, and learn more about the people they meet. They also develop their knowledge and skills by seeking different experiences.

Higher institution students' use of social media is happening in rapidly growing amounts as new technology becomes available. Computer-mediated communication allows students to interact over social media with family, friends and fan people (Baker \& Oswald, 2010).

Social network sites help to fulfill communication needs and wants. Users can manage their interactions within their own schedule by choosing when they want to read and respond. They also select the preferable media to communicate and interact with other people. However, it is effective because it is a one-to-many method of communication that allows users to quickly spread information. It is a permanent means of communication with different people, and it satisfies the users in different contexts.

Besides to communication, some students are using social media in their courses for communication with classmates, sharing of instructional resources, providing summaries, asking questions, taking exams, contributing to discussions, collaborative work, file sharing, evaluation, and following announcements in higher institutions. Hence, educational institutions are prefer student-centered teaching methods like innovative approaches, research, discussion, discovery, investigation, question and answer, demonstration, case studies, commenting on videos, inquiry, problem-based learning, project-based learning, group projects, collaborative and cooperative work. They apply the medium for teaching-learning process in different contexts and levels.

Internet makes unique features for communication and education to revolutionize the way most people live, interact, and harmonize the world. It helps to interact within and out of the state. Internet service exists in the country even though it is completely monopolized by the only state owned telecom service provider (i.e. ethiotelecom). According to Ali (2011), the internet has become the integral part of our economic, political, and social life. It changes the way we live, the way we bank, the way we communicate with one another and the way we educate.

Thus, the emergence of internet changes the way we live, it also offers the platform for the rising of different social media and social networking sites. Social media changes many aspects of relationships and communication. It also facilitates the way we communicate and educate. Today, we have a greater choice over the degree of privacy communication we want or the size of group we may wish to interact with. The phenomenon of the social media create motivation in young to adult, scholar to ordinary public that has engaged in the social media and social networking activity. It has different reasons why such media controls the people all over the world: simplicity, flexibility, accessibility, proximity are the reasons why people choose it.

As Kavitha (2016) stated, Ethiopia has 102,374,044 population statuses; in this, 4,500,000 are internet users in Jun 30, 2016, and the penetrations in percent of population is $4.4 \%$. Among these 4,500,000 are Facebook users.

According to Statusmonky data that stated in 2015, in Ethiopia, the most used social network is Facebook with the usage of about $97.84 \%$. Twitter ranks second with $1.15 \%$, Tumblr ranks third with $0.42 \%$, Vkontakte ranks fourth with $0.19 \%$ and the remaining social networks holds $0.4 \%$ using mobile internet.

Even if the social media has been blocked in state level because of state of emergency, many people use different methods to access Facebook. According to the freedom house report announced on August 8, 2016, "In recent days, Ethiopian government blocked social media message applications, including Facebook, Twitter, Viber and WhatsApp."

\section{Statement of the Problem}

Social media can offer a better and probably cheaper access to exchange of information around the globe for developing countries than the print medium. It is a flat form of communicational and educational media. In the context of universities, it helps cheaply to avail access to databases from all over the world in addition to communicating knowledge and skills to students.

It is the contention of this paper that the majority of university students in higher educational institutions do 
not have open link access to the internet for social media and they are not much familiar enough with it, and they didn't have any mediated access in order to fully utilize it as an educational and communicational resource. Furthermore, the researchers believe that they are not provided with necessary support from within the academic system in order to improve this situation and use it properly for effective communication and education tools. While the benefits of using the social media as a communication, teaching and learning tool in the university environment hasn't been well recognized, its impact in supporting the instruction and research needs of students in higher educational institutions of Ethiopia has been given little or no attention in most of the related literature (Lula Tewfik, 2007).

With regard to this, Debre Tabor University has a free outdoor Wi-Fi internet connection service in the campus that serves for the students, staffs, and gusts, but the institution didn't give any attention to social media usages. In today's technological world, relationship is created using social media all over the world. Introduction of smart phones has increased the use of these social media tools. Due to this, students use this social media for communication and education in informal ways. According to S. Kavitha stated on Ethiopian Herald, there are different social media websites which serves for communication, education and marketing in Ethiopia. These are: Facebook, Twitter, LinkedIn, Tumbler, YouTube, Flickr and Delicious.

In the mass communication process, uses and gratifications approach advocates that people's needs influence what media they would choose, how they use certain media and what gratifications the media give them. It also allows audiences personal needs to use media and responds to the media, which determined by their social and psychological background.

Therefore, the main intension of this research is assessing the use social media in DTU; how undergraduate students use the social media to support their studies and communications, and how they perceive its impact on their academic achievements. An attempt is also made to explore factors which deter the proper and extensive use of the social media within the university community. Therefore, assessing the significant determinants of social media use and the weight of its impact on their learning is crucial in setting targets aimed at improving the development, diffusion and use of the internet at all universities in Ethiopia.

\section{Objectives of the Study}

\subsection{General Objective}

The general objective of this study is assessing the use of social media in Debre Tabor University for Communication and Education with respect to undergraduate students.

\subsection{Specific Objectives}

Besides the general objective, this study specifically tries to:

- Distinguish the social media that are used in the Debre Tabor University for education,

- Examine how social media support students for their studies and communication,

- Identify the extent of social media in daily and academic lives of the participants,

- Explore the impact of social media on the undergraduate students, and

- Explore factors which deter the proper and extensive use of the social media within the university community.

\section{Significance of the Study}

Sociability is an underlying theme in using forms of social media. Since this social media phenomenon is continuing to grow at a fast pace, it is important to understand the effects it has on personal communication and education. Social media networks offer a straight forward way to converse with peers and get peer feedback. And also, social media have a great contribution for education; in teaching and learning processes. Now days, Facebook is used primarily by students to create and maintain relationships with individuals they are acquainted with who live near and far (Quan-Haase \& Young, 2010). Facebook makes it simpler to communicate with multiple people at the same time. Social media may also make it easier for users to monitor activities of people they have not seen in a while as well as reconnecting with new and old friends (Ibd). In the direction of this, DTU Students and staffs have been benefited from this study. In addition to this, it will show the way of social media as teaching tools in self-administered, collaborative learning and engagement to improve their performance. And also it will serve as a stand point for the other researchers.

\section{Methodology of the Study}

This study aims to assess the use of social media in DTU for communication and education particularly at undergraduate students. The study employed both quantitative and qualitative research methods. The data was gathered through a survey questionnaire distributed to 301 undergraduate students in the 2017 academic season to obtain information about their experiences and the impact of using social media on communication and education through use and gratification theory. 
The selection and construction of a measurement scale requires the consideration of several factors that influence the reliability, validity, and practicality of the scale (Cooper \& Schindler, 2006). The respondents were required to offer information of their experiences in using social media tools for communication and education. From the distributed questionnaires within 21 days duration, 49 questionnaires were found incomplete, thus, 285 valid responses were returned and analyzed.

\subsection{Data Collection and Measurement}

This study assesses the students' opinions about the use of social media for communication and education to improve their socialization and academic performance, and the underlying theories employed is uses and gratification. The questionnaire consisted of both open-ended and close-ended survey questions. The questionnaires pertaining to background information, the intention to use social media for communication, students' perception on social media tools for education and communication, and the influence of social media on educational performance of the students' and on their socialization. The questions aimed to measure the students' perceptions and preference of social media in communication and education and its influence on their academic performance.

\subsection{Sampling Techniques}

The study used a purposive sampling method to ensure a good representation of the target group that is DTU undergraduate students as users of the social media. In 2017 academic year in DTU, there are 24 undergraduate programs (i.e. 2,564 students). The researchers selected only 301 students as sample respondents. In one college and five faculties, 301 undergraduate students were selected as respondents for the questionnaires.

\subsection{Data Collection}

The data were collected between Jan 21- Feb 11 in 2017 using a survey questionnaire. The questionnaire was in paper versions. The questionnaire was addressed to the respondents by using the respondent's college/faculty. The graduate classes were targeted because they had good experiences and they are expertise for social media. There was also more likelihood of obtaining a sample graduate student. The questionnaire was pre-tested among 13 (i.e. 7 males and 6 females) students and adequate adjustments were made to clarify some questions that had earlier proved ambiguous.

\subsection{Data Gathering Instrument}

\section{Questionnaires}

The researchers were used questionnaire, which consisted open-ended and close ended questions, to gather the data from the sample respondents. This was a deliberate effort aimed at collecting rich data, especially with the qualitative questions that allowed students to articulate their opinions and provide richer responses as opposed to pre-packaged responses. Follow-up questions also provided opportunity for qualitative answers. Students were asked to check off the uses pertinent to them. Demographic information on age, gender, faculty/college and department was also obtained besides to education and communication questions.

\subsection{Data Analysis}

The questionnaire was entered in to SPSS software that provided a compilation of the raw data as well as a summary of responses arranged by questions. The data were downloaded onto an Excel spreadsheet and frequency tables, charts and graphs were drawn from the summaries. Data from the open-ended questions was coded to generate categories and, later, themes. The themes were then entered in an Excel spreadsheet from which pivot tables were generated for frequencies of responses.

\section{Theoretical Framework}

This study is done based on uses and gratification theory: Why do people use media and what do they use them for? Uses and gratification is concerned with what people (audiences) do with the media. Uses and gratification theory highly emphasis on the why and what question of the media usage. As Ruggiero (2000) stated, demassification is one method to examine new media. People use media for their different needs. Scholars suggest that media users seek out a medium source that best fulfills the needs of the user and they have alternate choices to satisfy their need (Blumler \& Katz, 1974). They also discovered that media served the functions of surveillance, correlation, entertainment and cultural transmission for both society and individuals (Ibd). People consume different messages with media in their day-to-day life. Interactivity takes the first place in social media. Uses and gratifications theory posits that people are active receivers of media messages and active influencers of the message effect. That is, the consumers of media messages have the freewill to decide how they will use the media and how it will affect them. People select preferable and appropriate media depend on their interests. As actively influencing the effect process, media audiences selectively choose, attend to, perceive and retain media messages. It indicates 
that audience activity suggests a voluntaristic and selective orientation by audiences toward the communication process.

The focus of this study is on media consumption functions. People are aware enough of their own media use, interests, and motives to be able to provide researchers with an accurate picture of that use (Katz et-al, 1974). Uses and gratification theory respects intellect and ability of media consumers. It indicates a positive relationship between social media usage and the level of gratification derived from such activity. It means that the media compete with other sources of need satisfaction. Generally, users of social media are motivated by similar intrinsic and extrinsic factors. In addition to these, utility, intentionality, selectivity and imperviousness to influence get inconsideration (Jay G. Blumler, 1979). As Katz, Blumler, and Gurevitch (1974) stated five basic assumptions; a framework for understanding the correlation between media and audiences. Scholars listed five motives of using social media as: meeting new people, entertainment, social events, maintaining relationships, and; media creation.

\section{Biographic Data}

\begin{tabular}{|l|l|l|}
\hline \multirow{3}{*}{ Gender } & & Count \\
\hline \multirow{5}{*}{ Age } & Male & 164 \\
\cline { 2 - 3 } & Female & 121 \\
\hline \multirow{5}{*}{ College/faculty } & $18-20$ & 28 \\
\cline { 2 - 3 } & $21-23$ & 211 \\
\cline { 2 - 3 } & $24-27$ & 41 \\
\cline { 2 - 3 } & 28 and above & 5 \\
\hline & Social Sciences and Humanity & 24 \\
\cline { 2 - 3 } & Natural and Computational Sciences & 67 \\
\cline { 2 - 3 } & Business and Economics & 40 \\
\cline { 2 - 3 } & Agriculture & 39 \\
\cline { 2 - 3 } & Health Sciences & 46 \\
\cline { 2 - 3 } & Technology & 69 \\
\hline
\end{tabular}

\section{Table 1: Background data of the respondents}

As it has been stated in the above table, 285(164 male and 121 female) from five faculties (Social Sciences and Humanities (24), Natural and Computational Sciences (67), Business and Economics (40), Agriculture (39), Technology (69) and one college (Health Sciences, (46) respondents were involved in this study. Participants were also in different age ranges. That means 28 (18-20), 211(21-23), 41 (24-27) and 5 (28 and above) were the participants that involved in this study.

2. Respondents' Usage of Online Social Networks and Possession of Social Media Profile.

\begin{tabular}{|l|l|l|l|l|}
\hline & & \multicolumn{2}{|l|}{ Do you have a social media profile? } & \multirow{2}{*}{ Total } \\
\cline { 3 - 5 } & & Yes, I have & No, I haven't & \\
\hline \multirow{2}{*}{$\begin{array}{l}\text { Do you use online social } \\
\text { networks? }\end{array}$} & Yes & 285 & 0 & 285 \\
\cline { 2 - 5 } & No & 0 & 0 & 0 \\
\hline Total & & 285 & 0 & 285 \\
\hline
\end{tabular}

Table 2: Uses of online social networks and social media profile of respondents

As stated above, $100 \%$ of participants use social media networks and they have social media profile. The researchers selected only the graduate class students which have close practice to the social networks.

As the data shows, all the respondents have social media profiles which opened online accounts due to different reasons and influences. As stated, social influences especially campus life and technological diffusion take the high contribution to access the online media profile. The first reason is that subjective norm influences them to use technology (i.e. smart phone (89\%), laptop (8.2\%), and tablet $(2.8 \%)$. The second reason is that group norms; it had its own significance. Most of Ethiopian higher institutions undergraduate students have similar interests that possess smart phone or laptop for their academic research or project purpose. In addition to these, the social identification of the students influences to have modern electronics tools and use of social media shows their status in the campus community. 


\section{Type(s) of Social Media Used by Respondents and their Ranks}

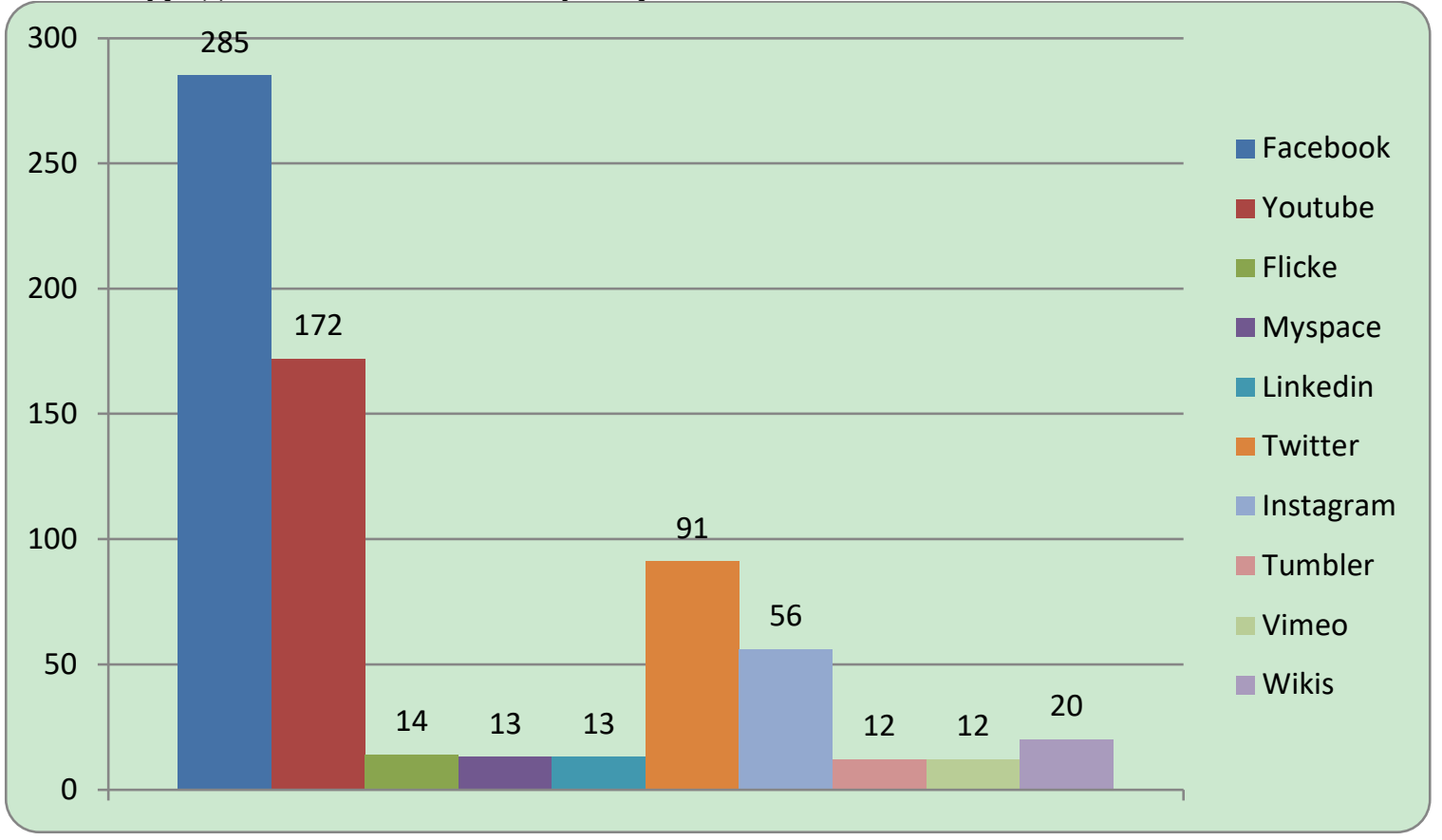

Figure 1: Types and ranks of social media that students use

As the above statics shows, most of the students have different social media profiles. They are in favor of Facebook (100\%) and placed at the first poison, whereas YouTube (52\%) takes the second place, and also 20\% of participants prefer twitter and give third place. The others (Instagram, Wikis, Flicke, Linkedin, Myspace, Tumbler and vimeo) are in use, in DTU undergraduate students' succession. Obviously, other social media (delicious, Vkontakte, SnapChat) were not popular in the DTU students. Participants haven't heard about these media. Due to that they can't rank them. When the users want to interact with other groups, such as family, friends or relatives, pupils use Facebook where pupils welcome strangers who can appreciate their image use Instagram.

In Ethiopia, most of the students are preferred to Facebook to communicate with their friends and different people. Here in DTU have the same practice how they use Facebook in the communication practice. The respondents were also close to YouTube to watch and download different movies, music, and dramas. In addition to these, they are close to use twitter and Instagram to follow popular people and post their selfie photographs. Now a time, most of the youth generation has high consumptions of new media.

\section{The type(s) and capacity of connection they use}

\begin{tabular}{|c|c|c|c|c|c|}
\hline & & \multicolumn{3}{|c|}{ Capacity of the network that you use? } & \multirow[t]{2}{*}{ Total } \\
\hline & & Strong & Weak & No access & \\
\hline \multirow{5}{*}{$\begin{array}{l}\text { Which type(s) of } \\
\text { connection do you use? }\end{array}$} & Wi-Fi & 37 & 74 & 1 & 112 \\
\hline & Mobile data & 7 & 71 & 3 & 81 \\
\hline & Wi-Fi \& Mobile data & 36 & 55 & 0 & 91 \\
\hline & Cable & 0 & 1 & 0 & 1 \\
\hline & Total & 80 & 201 & 4 & 285 \\
\hline
\end{tabular}

Table 3: Types and capacity of network connection that respondents used

As indicated above, most of the respondents, 39.3\% were use Wi-Fi connection while $31.9 \%$ were used WiFi and Mobile data connection. $28.4 \%$ of the respondents were also use only mobile data connection. Even if they use different types of connection, $70.5 \%$ of the respondents replied that the network capacity was weak, and also $28 \%$ respondents' believed that the network connection capacity was medium or strong.

Accordingly the cross tabulation data indicated, most of the students were use Wi-Fi connection which has weak network capacity. DTU has outdoor open Wi-Fi network access to the students, staffs and guests. Most of respondents use this connection to communicate with their online friends and to search academic materials. Conversely, the network capacity is weak because the number of the users and the capacity of the connection are not proportionate. As DTU ICT data indicated that the capacity and coverage of the network is insufficient.

In addition to this, in Ethiopia the connection is run by the ethio-telecom that is administer under government 
control. Then, the facility is poor and blocked depend on the political situation of the country. During the time of data collection, social media was blocked due to political instability, since state of emergence announced for six months, and it also continued four months. This state of emergency totally or partially controlled and blocked social media in Ethiopia depend on the situations of the political instability.

5. Respondents' electronics mediated tools used for social media communication and their technology usage and attitudes

\begin{tabular}{|l|l|l|l|l|l|l|}
\hline & & \multicolumn{3}{|l|}{ Rate your technology use and attitudes } & Total \\
\cline { 3 - 6 } & & Low & Moderate & Enough & High enough & \\
\hline $\begin{array}{l}\text { Which type(s) of } \\
\text { electronics }\end{array}$ & Laptop & 0 & 10 & 8 & 2 & 20 \\
communication tools do & SPL* & 12 & 9 & 19 & 4 & 44 \\
you use for social media & Smart phone & 78 & 93 & 37 & 2 & 210 \\
usage? & Desktop & 3 & 0 & 0 & 0 & 3 \\
\hline Total & Tablet & 1 & 5 & 2 & 0 & 8 \\
\hline
\end{tabular}

Note: * - Refers smart phones and laptops

Table 4: Electronics mediated tools that respondents use for social media communication and their technology usage and attitudes

As indicated above, $73.7 \%$ of respondents respond that they primarily used smart phone, $15.4 \%$ laptop and smart phone, $7 \%$ laptop, $2.8 \%$, tablet and $1.1 \%$ desktop to check and use social media sites. Similarly, when we see their technological use and their technological attitudes, they have different skills. As shown above, $41.1 \%$ of the respondents assured that they had moderate technology use and attitudes, 33\% of them have low technology use and attitude, $23.2 \%$, and $2.8 \%$ had enough and highly enough technological use and attitudes correspondently.

Internet performs to have become an inherent part in human lives for both professional and personal activities. The computer usage and ability to go online has become a norm, especially among young people, who are now called the "net generation" (Tapscott et-al, 2011). This generation, here in DTU uses electronics mediated communication tools especially smart phone to communicate and find out different materials for their education. New digital technologies allow new forms of education innovation and creativity (Grabarczyk-Tokaj M., 2013). The increasing speed of communication, interaction and networking can create innovation, but also force the continuous improvement of competence and adaptation to the fast-changing socio-economic environment.

Those, for whom keeping up with the adoption of new technologies is easy to adopt new tools that support them in communication and education, due to those DTU students have moderate technology usage and attitude. Their attitudes and skills for technology increase their speed of communication and interaction.

6. Respondents' frequencies to visit and times spend on social media sites in a day

\begin{tabular}{|c|c|c|c|c|c|c|}
\hline & & \multicolumn{4}{|c|}{$\begin{array}{l}\text { How often do you spent daily on social network } \\
\text { sites? }\end{array}$} & \multirow[t]{2}{*}{ Total } \\
\hline & & $\begin{array}{l}15-30 \\
\text { minute/day }\end{array}$ & $\begin{array}{l}30-60 \\
\text { minute/day }\end{array}$ & $\begin{array}{l}1-2 \\
\mathrm{hrs} / \text { day }\end{array}$ & $\begin{array}{l}\text { More than } 3 \\
\text { hrs/day }\end{array}$ & \\
\hline \multirow{5}{*}{$\begin{array}{l}\text { How many times do } \\
\text { you visit social } \\
\text { media sites in a day? }\end{array}$} & Once a day & 42 & 28 & 11 & 0 & 81 \\
\hline & Twice a day & 16 & 43 & 22 & 3 & 84 \\
\hline & Three times a day & 13 & 19 & 29 & 3 & 64 \\
\hline & More than four times & 10 & 9 & 22 & 15 & 56 \\
\hline & Not at all & 0 & 0 & 0 & 0 & \\
\hline Total & & 81 & 100 & 84 & 21 & 285 \\
\hline
\end{tabular}

Table 5: Respondents response how may time to visited and spent on the social media sites

The result of the survey questionnaires indicated that $29.5 \%$ of the respondents admitted that they visited social media site two times in a day, $28.4 \%$ of the respondents also disclosed that they visited social media sites one times in a day, $22.5 \%$ and $19.6 \%$ replied that they visited social media sites three times and more than four times in a day respectively. Respondents also were asked that how often they spent daily on social networks. $35.5 \%$ of the respondents spent 30-60 minute in a day to checking social media sites while $29.5 \%$ of them spent more than 1-2 hours in a day; $28.4 \%$ of them also spent $1-2$ hours in a day. Only $7.4 \%$ of respondents were spent more than three hours per a day on social network sites.

According to the data, most of the students would prefer to visit social networks and to use social media. They spent vast hours checking social media sites. That is more than $50 \%$ of the respondents were spent more than one hour in a day especially Facebook. They have different reasons why did visit social media in different frequencies and spent much time on it. As they stated, they use it in cafeteria, library and dormitory to communicate 
and browse information. That means, they used it as refreshment; luxury time.

This indicated that the students are using social media for different purpose, especially for communication and resource sharing. The students' demand of network was high to connect with social media sites and use it because there was not anything in the campus for entertainments.

7. Gender and age that respondents most of the time communicate in social media

\begin{tabular}{|l|l|l|l|l|l|l|l|l|}
\hline \multicolumn{2}{|c|}{} & \multicolumn{3}{|l|}{ In which age stage people do you communicate often? } & Total \\
\cline { 3 - 11 } & $13-17$ & $18-22$ & $23-27$ & $18-27$ & $28-32$ & $\begin{array}{l}\text { Above } \\
\text { years old }\end{array}$ & \\
\hline \multirow{2}{*}{$\begin{array}{l}\text { With whom most of the } \\
\text { time do you communicate } \\
\text { using social media? }\end{array}$} & Males & 3 & 15 & 10 & 1 & 2 & 1 & $\mathbf{3 2}$ \\
\cline { 2 - 11 } & Females & 4 & 19 & 12 & 3 & 1 & 0 & $\mathbf{3 9}$ \\
\hline Toth & 5 & 98 & 76 & 32 & 2 & 2 & $\mathbf{2 1 4}$ \\
\hline
\end{tabular}

Table 6: Age and sex of the people that the respondents need to communicate

As stated in table 7, respondents confirmed that most of the them $(75.1 \%)$ need to communicate with males and females in the age of $18-27(93 \%)$; however that, $13.7 \%$ of respondents need to communicate with only females and $11.2 \%$ wanted to communicate with only males. while $4.2 \%$ of the respondents need to communicate with in the age of $13-17 ; 1.8 \%$ communicate peoples in age of $28-32$.

Internet has an impact upon gender. Anonymity online can enabled people to appear with an entirely different persona, such as crossing gender. Internet made it seem that online might become an unprecedented liberal space allowing women and men to freely perform their own created identities. Most of the students in DTU were from the rural area that the male dominance exercises. The platforms help them communicate freely with different people in different age. Social media has become an important tool for females to communicate with an extended network of people and to maintain social relationships when these may be somewhat limited in offline contexts. DTU undergraduate class students are youth and they need to communicate with different genders to share and to transform themselves in different contexts. The data also assured that most of the respondents need to communicate with males and females in the age of 18-27.

8. Usages of Social Media in DTU Students

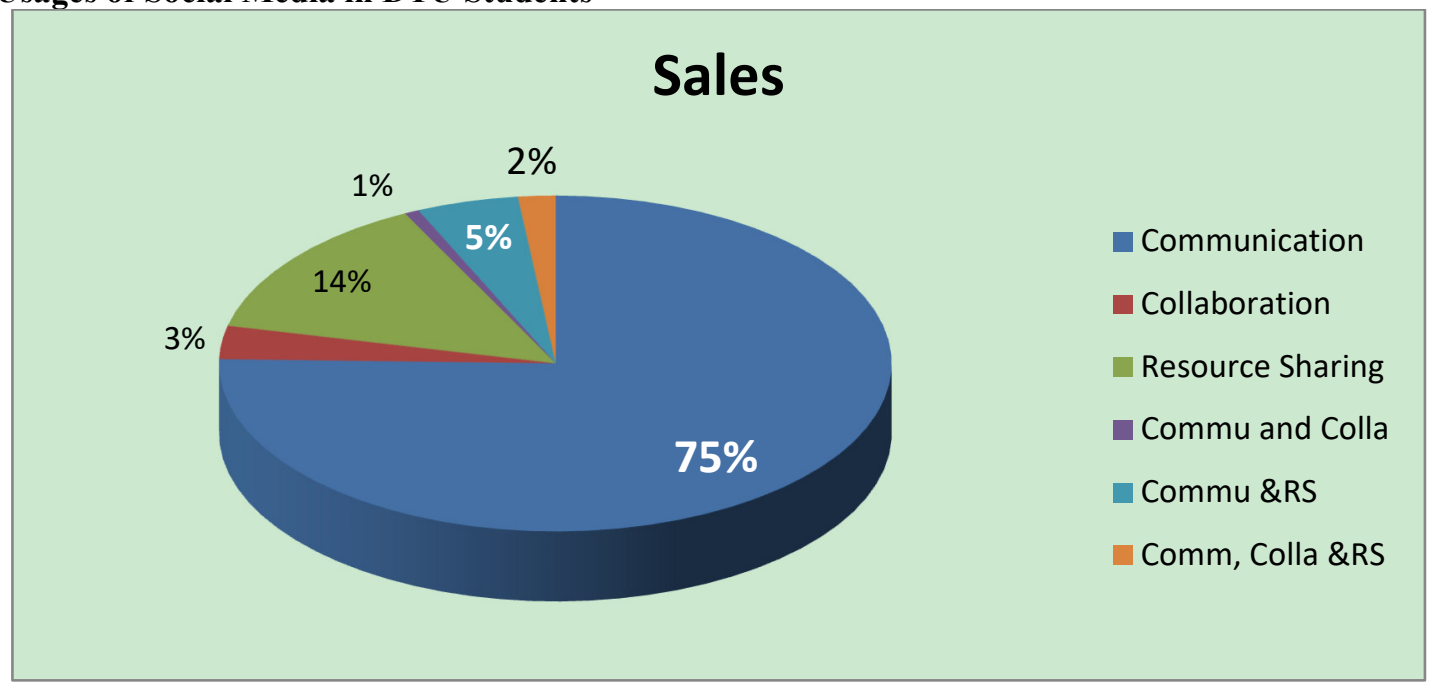

Figure 2: Use of social media in DTU Students

As indicated in fig two, $75 \%$ of the respondents replied that they use social media regularly for communication, $14 \%$ of also use it for resources sharing, the rest collaboration, communication and resource sharing covers $11 \%$ together. Besides to this, as the respondents were stated, they use others social media (imo, viber and whatsup) for communication.

In connected to this, Aditi Grover and David W. Steward (2010) stated social media tools are rapidly changing the communications landscape. Social media helps for small group communication and private communication such as messaging services. And it also enables continually communication that groups can post to anyone else and interact with the posted message. In addition to this, the development of ICTs, and the emergence of social media and smartphones, has radically reshaped communication practice for many people, especially for developing countries. This is the reason how undergraduate students use social media for communication. If there are many alternatives, people have the option to use different media to communicate with; the platform people choose can have significant consequences for their social relationships. This wills the reason most of the students in DTU seek 
information in scalable sociality to communicate by using this platform media. $75 \%$ of the respondents were use social media for communication because they know the media contents, and which media can use to meet their needs. The main-stream media couldn't satisfy youth needs of information, and it has one-to-many communication nature. Furthermore, almost all national and regional media are controlled by the government that exercises development journalism.

Respondents use and gratify based on their interest because social media is scalable sociality. Social media provides greater control in communication over both the degree of privacy and size of group, when compared with previous forms of communications media (i.e. traditional media).

Social media emergence has impacted significantly how students learn and the way instructors teach. In todays, higher education settings, instructors, students, and others collaborate on the tasks of knowledge construction (Aditi [et-al], 2010). Some of the respondents also use social media for resource sharing with their friend in the campus and with other university students because they are networked publics. The capabilities which a platform makes available to users such as qualities like persistence, visibility, spreadability and searchability (Boyd and Ellison, 2007).

\section{Respondents' Social Media Usage in their communication}

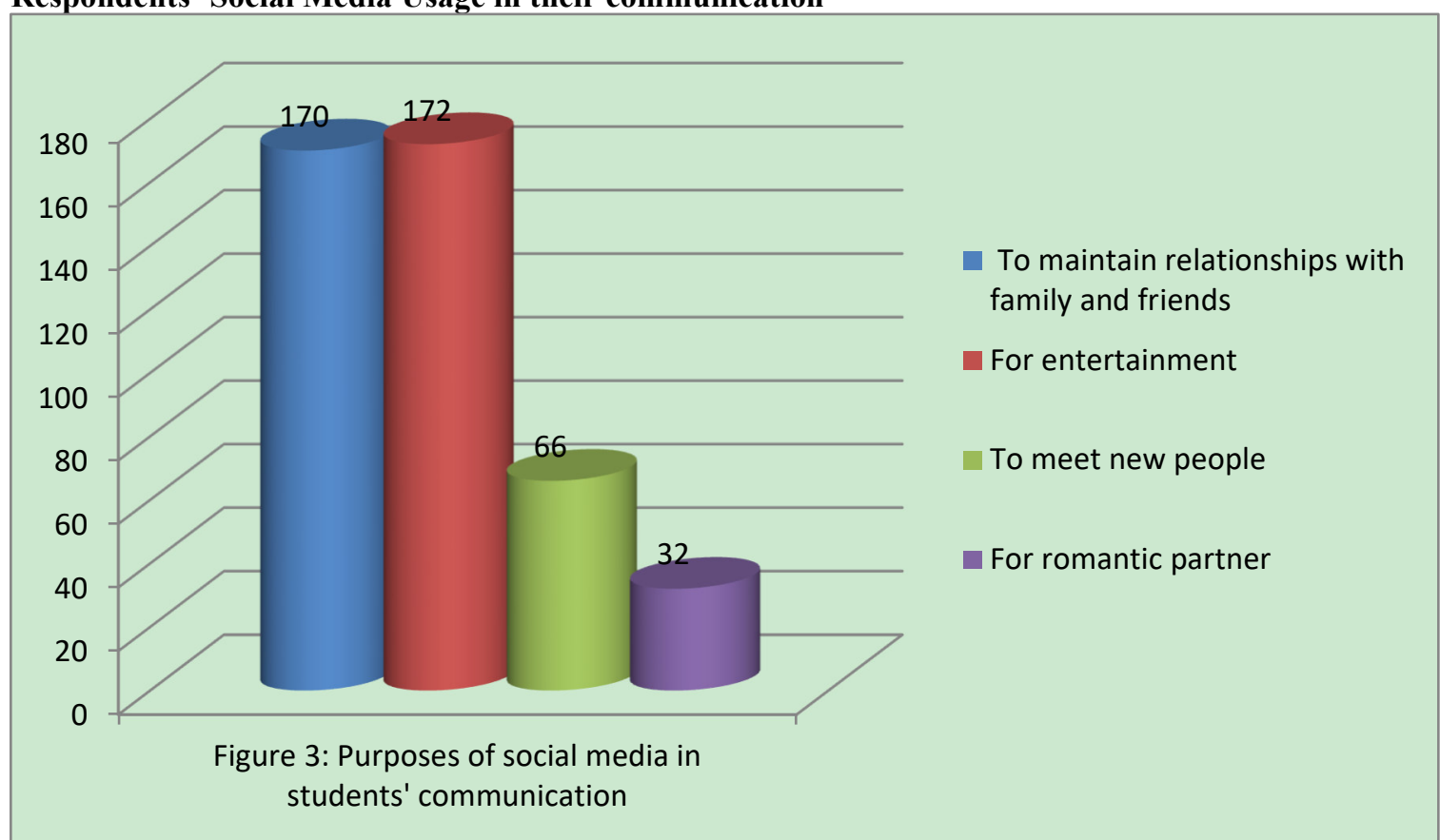

As indicated in fig three, $60.4 \%$ of respondents confirmed that they use social media especially Facebook for entertainment, $59.6 \%$ of them also use it to maintain their relationships with their family and friends, $23.2 \%$ of the respondents too use the media to meet new people, while $11.2 \%$ of the respondents use it for romantic partners. They stated that how they use social media in forms of 'pass time'; entertain themselves by watching different movies and video music and playing online games.

As shown in figure 2, most of the respondents were used social media for communication. As defined above social media as online service, platforms, social communication and relations can be established, and individuals share information. People used social media to express their values and aspirations within their own particular communities. The respondents use this media to communicate and maintain their relationships in forms of image, text and voice. Communication has the function to enlighten the public with different tiresome, so as to avoid such boringness people have to make a communication with someone. Most of the students posted their selfie and meme photographs on social media as communication means. 


\section{Respondents' activities performed on social media}

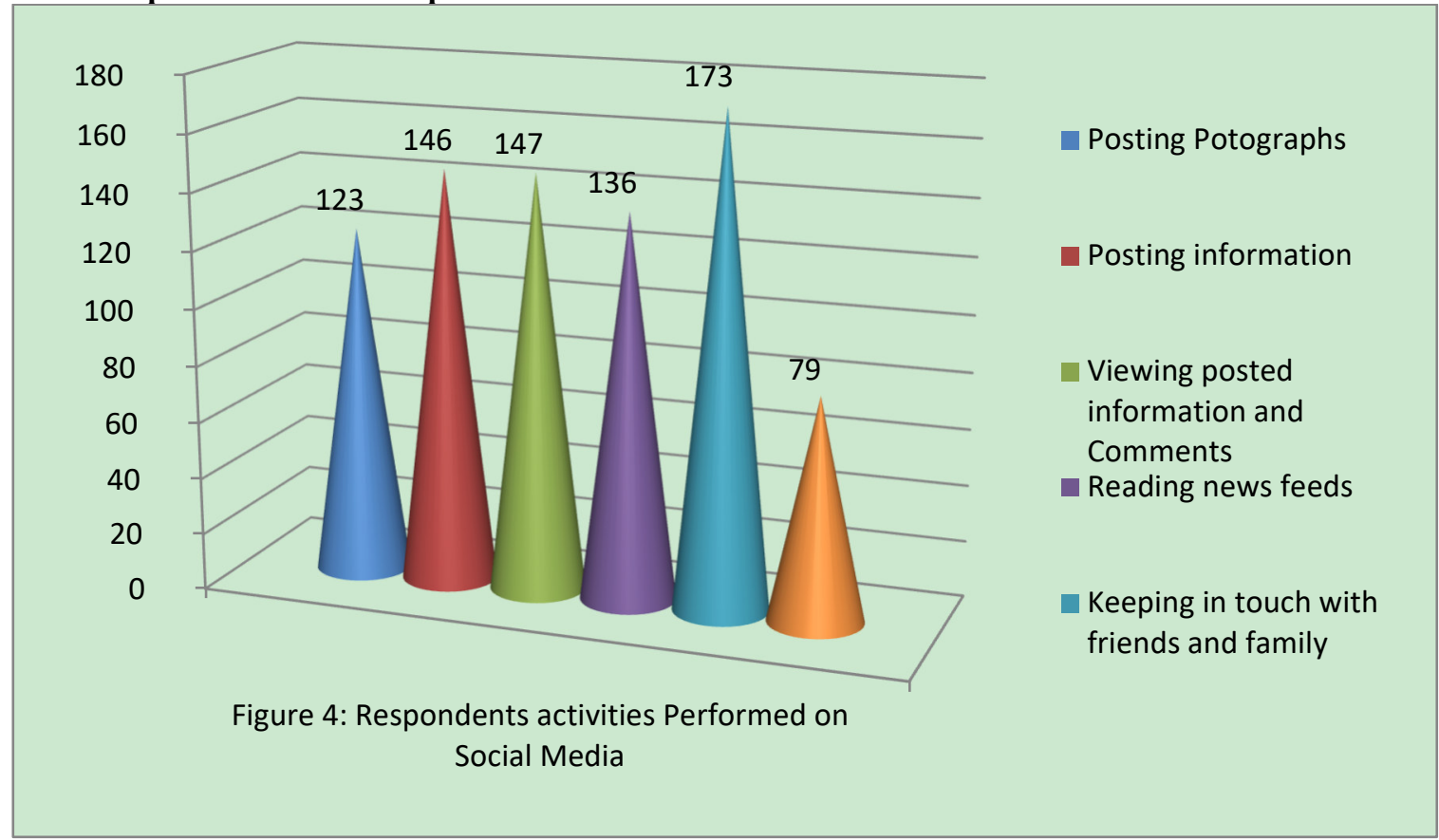

As indicated in fig four, $60.7 \%$ of the respondents stated that they use social media to keep in touch with their friends and family, $51.6 \%$ of the respondent also replied that they use social media to view posted information and comments, $51 \%$ of them use for posting information about themselves, $47.7 \%$ also use for reading news feeds, whereas $43 \%$ of them use for posting photographs and $27.7 \%$ use for entertainment.

The fundamental characteristics of social media are the creation of community; a fellowship and relationship with others who share common attitudes, interests and goals (Maggiani, 2014). As the above data shows high present of DTU students use social media for communication; keeping in touch with their friends and family.

Students in their university life create strong ties that referring to close social relationships such as those between family and close friends because they lead their life independently in the campus. They live far away with their family. Due to these, they create high and continuous relations with different people. It helps those building social capitals and learning about the others and share different attitudes, cultures, behaviors etc.

\section{Students' interest and their instructors' willingness to be friend in social media}

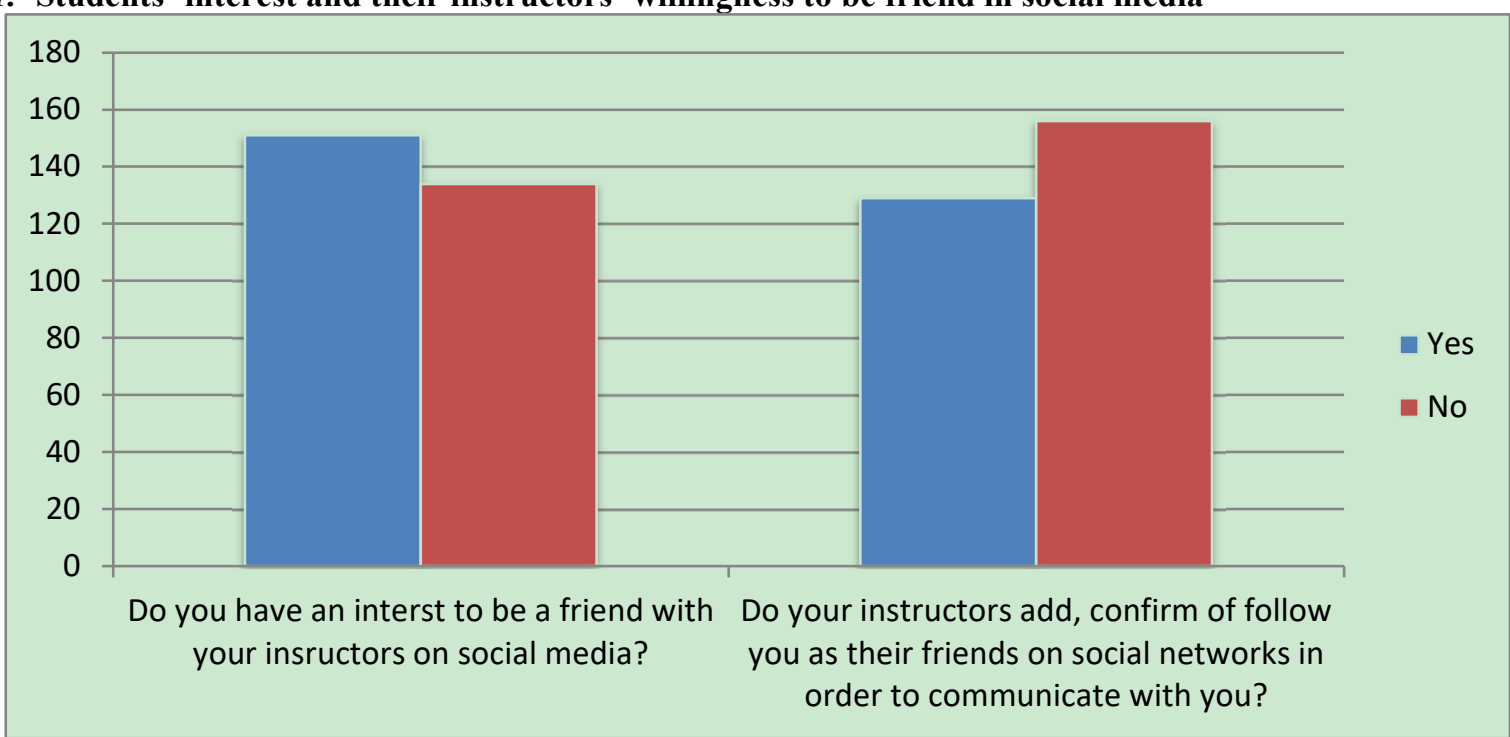

Figure 5: Students' interest and their instructors' willingness to be friend in social media

The above fig. shows that $53 \%$ of the respondents testified that they have an interest to be a social media friend with their instructors, whereas $54.7 \%$ of the respondents replied that their instructor didn't add, confirm or follow them as a social media friend to communicate and share different resources. Besides this, open-ended question were asked the respondents.

Students had good perception for social media and they have an interest to be social media friends with their 
instructors or follow them. They stated that many reasons why they want to be friend with their instructors; they need to get close advice regarding to education and life experiences, to share ideas, knowledge, educational materials, to create long-life relationships, and to communicate with the instructors at any time. The respondents have a good understanding about social media which serves as informal learning tools. Universities to equip students properly with the skills and knowledge they required for success in formal education, work, and life. In response, many young people inventively appropriated social media to provide supplementary means of learning. Due to that respondents show their interest to be friend with the nearest instructors' and senior students'.

On the other hand, the instructors didn't add or confirm their students as social media friends. As the respondents confessed that the relationship between students and their instructors are not good, instructors of DTU haven't willingness to communicate with their students through social media. In addition to this, most of the instructors are not use their real name to open social media account, so it is difficult to send them friendship request or follow them. Conversely, they stated their frustration; to be friend with instructors has problems: it touches the privacy of the users (students); students didn't feel comfort to use social media freely.

Concerning to privacy, both for the instructors and their students were uncertain to maintaining the class as a private space for free and open discussion, communication.

\section{Respondents' interest in teaching methods that will implement in social media environments in DTU}

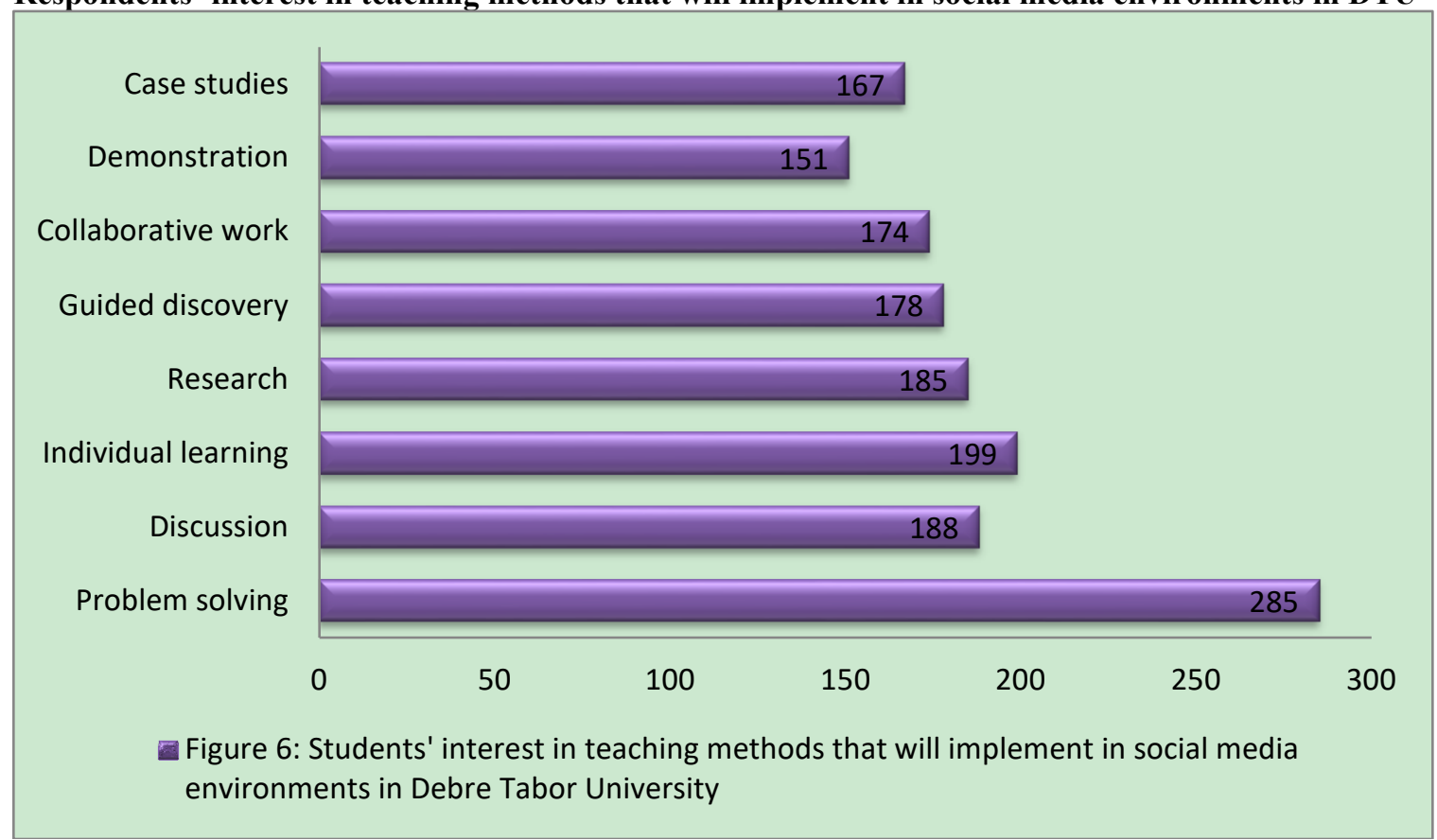

The above statics shows that all of the respondents have an interest to use social media for education as problem solving $(100 \%)$, individual learning $(69.8 \%)$, discussion $(66 \%)$, research $(64.9 \%)$, guided discovery $(62.5 \%)$, collaborative work $(61.1 \%)$, case study $(58.6 \%)$ and demonstration $(53 \%)$. Social media have many advantages in education. It increases student collaboration, participation and interaction. We have to add a social learning interface to both Pearson learning studio and open class learning management systems. Social media also provides the opportunity for communication, professional development, and collaboration among members of teaching and research staff, information services staff, and administrators (Nicola Osborne, 2011).

Higher education institutions are using social media to engage with an audience well versed in new media channels. Social media is seen as a viable tool for university communicators due to its low cost, immediacy, and use by a large number of students (Kelleher \& Sweetser, 2012). Students learn through exploration as well as affording them partial access to wider public spheres. Students in DTU had a great interest to use of social media as teaching-learning tools because different factors and importance of the tools increase their interest.

13. Respondents' interest rank in teaching methods that will implement in social media environments in DTU

The respondents were asked in the above figure to state their interest in teaching methods that implement in social media environment in DTU. And also the respondents were given the rank to teaching methods that wish to implement in social media. 


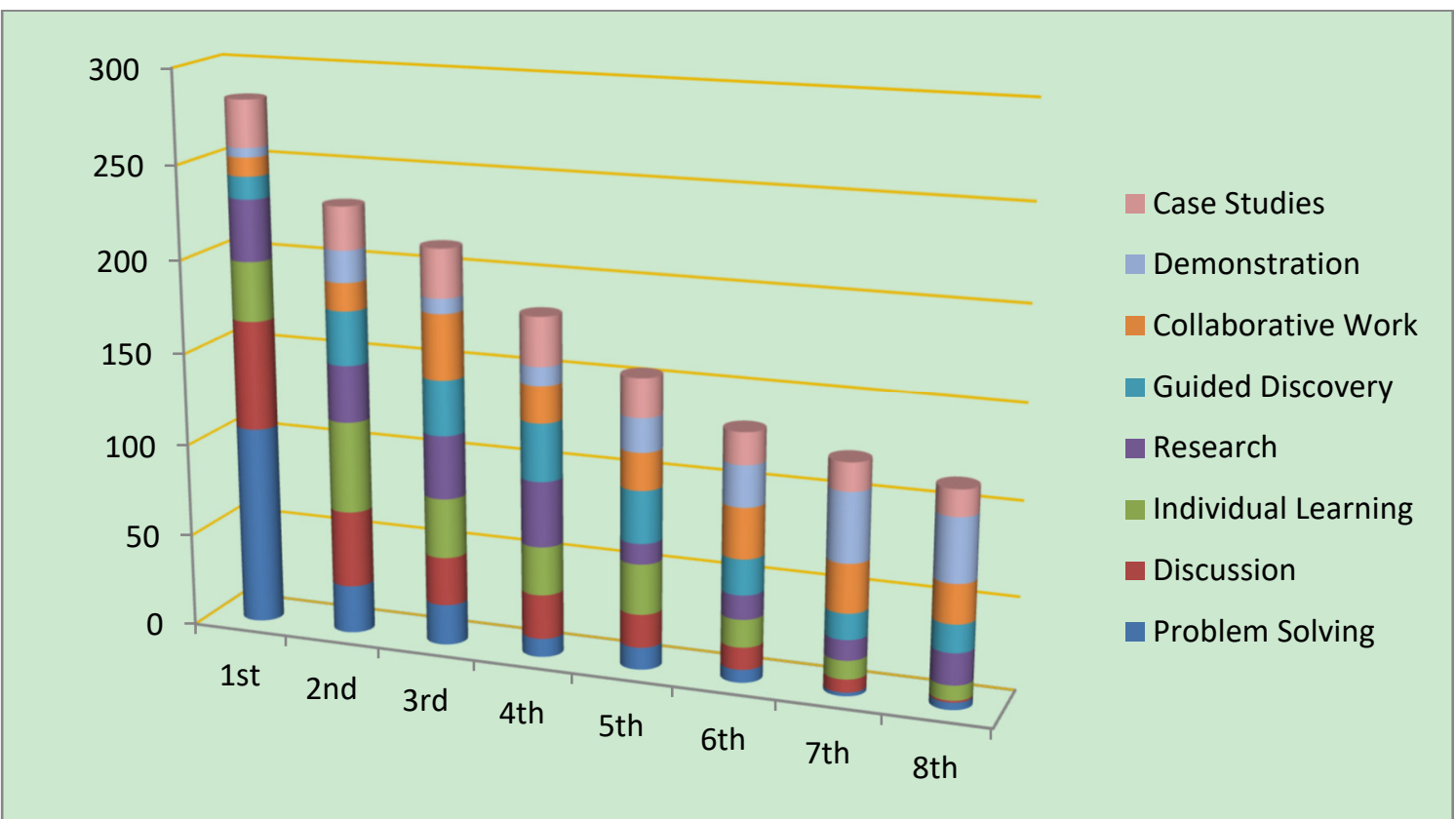

Figure 7: Respondents' interest rank in teaching methods that will implement in social media environments in DTU

As indicated series one, all respondents confirmed that they have an interest in using social media for teaching as problem solving methods; however, they had different arguments in placing range for problem solving. $37.5 \%$ of the respondents placed first rank, $9.1 \%$ of the respondents also rank the second position, and $7.7 \%$ of them placed in third stage.

Moreover, as it has been shown in series two, $66 \%$ of the respondents have an interest to social media in education as a discussion methods of teaching; amid of these, $20.7 \%$ of them placed in first place, $14.4 \%$ of takes the second place and $9.4 \%$ bounces third stage.

As can been vividly indicated in series three, $69.8 \%$ of the respondents replied that they have an interest of using social media as individual learning tools; on consequence of that, $16.8 \%, 11.9 \%, 11.2 \%$ paced as $2^{\text {nd }}, 1^{\text {st }}, 3^{\text {rd }}$. In series four also, $64.9 \%$ of the respondents have an interest to use social media for research, and they placed as $12.3 \%, 11.9 \%, 11.9 \%$, and $10.5 \%$ as $4^{\text {th }}, 1^{\text {st }}, 3 \mathrm{rd}$ and $2^{\text {nd }}$.

As it has been shown in series five, $62.5 \%$ of the respondents have an interest in using social media for guided discovery and they gave $10.9 \%, 10.5,10.2 \%, 9.8 \%$ as $4^{\text {th }}, 3^{\text {rd }}, 2^{\text {nd }}$, and $5^{\text {th }}$ respectively. In series six also, $61.1 \%$ of respondents replied that they have an interest to use social media for collaborative work. They gave rank for their interest as $3^{\text {rd }}(12.3 \%), 6^{\text {th }}(/ 9.5 \%)$, and $7^{\text {th }}(9.1 \%)$.

As shown in series seven, $53 \%$ of the respondents were preferred social media for demonstration teaching method that has $13 \%, 11.9 \%, 7.7 \%, 18(6.3 \%)$ as a rank of $7^{\text {th }}, 8^{\text {th }}$ and 6 th. And as stated in the last, 58.6\% respondents confirmed that they have an interest to use social media for case study teaching method. They give equal rank as $1^{\text {st }}, 3^{\text {rd }}$, and 4 th by giving $26(9.1 \%)$.

Generally, DTU undergraduate students have high interest to use social media for teaching learning tools, and they stated their motives that social media aimed at teaching methods.

Social media has expanded and has transformed the way we interact with one-another-in different levels. Now a time being, blogging site serve as a forum to share content, encourage debate and answer queries, with some even setting up hash tags for individual courses to create online discussion communities for their students in different circumstances. In addition, social media serve for resource sharing, discussion forum, research, guided discovery and demonstration.

Social media can create opportunities for friendship that are driven by peer-to-peer learning, and that these interactions in turn foster their skills in social media (Ito M. 2010). The interactions in turn foster their skills in social media and other activities. Most scholars argue that by 'hanging out' and 'messing around' online, young people learn through exploration, as well as affording them partial access to wider public spheres. Boyd (2014) and Clark (2013) demonstrate how problems, such as the rise of screen interaction as against face to face interaction, associated with social media use are often unfairly attributed to young people's behavior.

If it implemented in DTU as teaching methods, it will serve to distribute lecture notes and other course information. Lecturers can push content automatically to apps like Twitter, Facebook or LinkedIn. The students also use to discuss with their peers, and use it as a chat forum where students can communicate with their lecturers and with each other because most of the students possess smartphone and they use social media actively. Social 
media does not merely allow knowledge transfer but it also facilitates students' collaborative learning to creating understanding among students, discussion with peers, lecturers, increase knowledge sharing, and improve research students skills (Redecker et al., 2010).

\section{Negative effects of social media on students' academic performance}

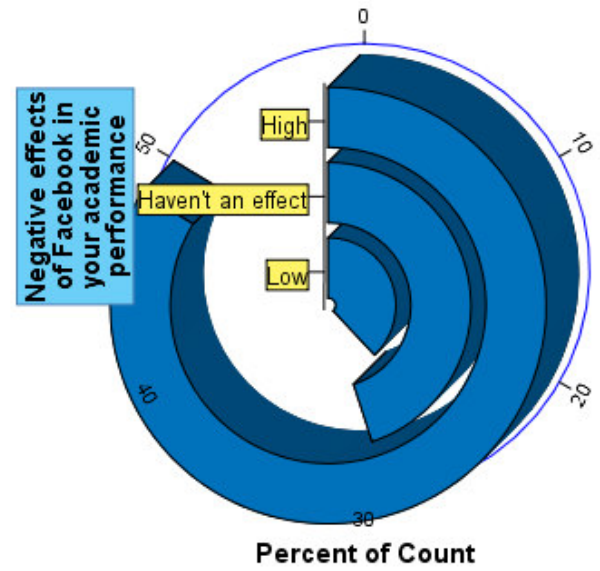

Figure 8: Social media negative effects on students' academic performance

As shown in fig 8, students were asked the negative effects of social media on their academic performance. Accordingly, above $50 \%$ of the respondents believed that social media has high negative effect on their academic performance. Conversely, $27 \%$ of also respondents respond that it hasn't any negative effect on their academic performance, and $22.8 \%$ of also believed that it has effect on the academic performance but the effect is low.

As the respondents confirmed that they use social media without guidance, and they haven't much awareness about the proper use of social media. They use different exposer to communicate and post their photos. Besides of this, the main stream media didn't inform or aware them how they use social media, higher institutions too. The institution hadn't any policy and guidance for social media usage.

Above $72 \%$ of DTU undergraduate students spent more than one hour per day to check social media sites for communication and entertainment, so it affects students' efficiencies as well as grade. This improper usage of social media without the institutional guide and social media usage policy will bring effects on the students' academic performance and quality of education.

Social media have positive and negative effects; however, the question to be how we use social media positively for education'. That means it has good opportunities if we use properly. Indeed, the most common use of social media in higher education is as a means of amplifying existing events, publications, and websites.

Even though social media have positive importance, sometimes it also brings potential risk. Social media are faster and less formalized process than traditional media; it can be advantageous to create appropriate organizational policies, procedures, and guidelines. The most successful social media guidelines and policies are encouraging and nurturing in tone, highlight good practice and clarify the appropriate use of these tools. They must also specify material that is not appropriate for sharing, and indicate some form of process for dealing with conflicts arising from social media interactions (Nicola Osborne, 2011, Solis, 2008).

15. General DTU undergraduate students' social media usage in communication

\begin{tabular}{|l|l|l|l|l|l|}
\hline No. & Platforms: Do you use social media for; & \multicolumn{2}{l|}{ Yes } & \multicolumn{2}{l|}{ No } \\
\cline { 3 - 6 } & & $\mathbf{F}$ & $\mathbf{\%}$ & $\mathbf{F}$ & $\mathbf{\%}$ \\
\hline 1 & Sharing photos, videos, music and information liberally? & 218 & 87.7 & 35 & 12.3 \\
\hline 2 & Providing your opinion to mainstream media & 136 & 47.7 & 149 & 52.3 \\
\hline 3 & Knowledge sharing & 151 & 88.1 & 34 & 11.9 \\
\hline 4 & $\begin{array}{l}\text { Horizontal interaction including creating, sharing, and downloading of } \\
\text { contents in different formats }\end{array}$ & 253 & 88.8 & 32 & 11.2 \\
\hline & & & & & \\
\hline 1 & Getting latest news? & 242 & 84.9 & 43 & 15.1 \\
\hline 2 & Discovering new music, films, books, and other entertainment? & 210 & 73.7 & 75 & 26.3 \\
\hline 3 & To access up to date knowledge & 238 & 83.5 & 47 & 16.5 \\
\hline
\end{tabular}

Table 7: Respondents' platform use for communication

As indicated above, most of respondents confirmed that they were active social media users; they use social 
media to share photos, videos, music and information liberally $(87.7 \%)$, to share knowledge $(88.1 \%)$, to interact horizontally including creating, sharing, and downloading of contents in different formats (i.e. text, video, data, audio and picture) $(88.8 \%$ ) while $52.3 \%$ of the respondents didn't provide their opinion to the main stream media.

Besides of these, the respondents were use social media for getting latest news $(84.9 \%)$, for discovering new music, films, books, and other entertainments $(73.7 \%)$ and to access up-to-date knowledge $(83.5 \%)$.

Social media are characterized by participation, openness, conversation, connectedness, and sense of communality (Mayfield, 2008). Respondents mainly used social media for socialization and other purposes such as networking, seeking information and communication. The students use social media for posting their photos and videos in different time and occasions to show their activities and performances. When they did their project, when they were at filed trip or research, when they celebrate different festivity in the campus and out of the campus, they take photos and videos and post and share it. Besides of this, they use the social media for networking which helps them to communicate and to share educational information and materials with in different university students.

As stated, they participate actively in the platforms. They share their experiences and knowledge with their friend. And also they can download and documented the important materials. However they were not interested to provide their experiences and opinions for the mainstream media, because the old media formats didn't gratify their need and interest.

Internet use now being a participatory and collective activity is reflected in the language used to describe social media applications. Social media constitute an increasingly important context where in individuals live their everyday lives. Indeed, some commentators' are talk of the 'networked self'-acknowledging the importance of social media as a key site of sociality and identity performance in many people's lives (Papacharissi, 2010).

Respondents were active and they can understand the use of social media that address latest information; they seek news, new movies, and books, update knowledge and update themselves. As Tapscott and Williams (2007) continue, young people are not content to be passive consumers, and increasingly satisfy their desire for choice, convenience, customization, and control by designing, producing, and distributing products themselves'. This social media also serves them to seek job information after they graduated.

Participants engaged with online content in a number of ways closely related to the type of platform they used and the purpose they used it for. These types of engagement saw users fall into three distinct but overlapping roles: creators, sharers and observers.

\section{Social Media in Education}

A. Human Values

\begin{tabular}{|l|l|l|l|l|l|l|l|l|l|l|}
\hline Use of social media in education & \multicolumn{2}{l|}{$\begin{array}{l}\text { Very } \\
\text { poor }\end{array}$} & \multicolumn{2}{l|}{ Poor } & \multicolumn{2}{l|}{$\begin{array}{l}\text { Not } \\
\text { at all }\end{array}$} & \multicolumn{2}{l|}{ Good } & \multicolumn{2}{l|}{ Excellent } \\
\cline { 2 - 11 } & F $\%$ F & F & $\%$ & F & $\%$ & F & $\%$ & F & $\%$ \\
\hline $\begin{array}{l}\text { Use the social media platform in order to learn } \\
\text { the human values, such as love, respect, } \\
\text { helping, and responsibility? }\end{array}$ & 59 & 20.7 & 64 & 22.5 & 25 & 8.8 & 111 & 38.9 & 26 & 9.1 \\
\hline $\begin{array}{l}\text { Share or post indigenous knowledge, about } \\
\text { affective values }\end{array}$ & 45 & 15.8 & 75 & 26.3 & 39 & 13.7 & 94 & 33 & 32 & 11.2 \\
\hline
\end{tabular}

Table 8: Respondents' social media usage as human values

As indicated above, $48 \%$ of the respondents replied that they use social media platform in advance to learn the human values, such as love, respect, helping, and responsibility, $43.2 \%$ of them was poor in their social media usage. As the respondents confirmed $44.2 \%$ of social media users had a good experiences in sharing or posting indigenous knowledge for affective values, while $42.1 \%$ of the respondents also had poor and very poor experiences to social media for human values.

Users learn different issues in social media especially human values. Passive users were learning more about the human values. Due to that they like, share, twit and observe the information, romantic stories, stories that honor elders and promote people, helping the others and what are the responsibility of each people were significant. They sharing and posting seasonal or situational poems, proverbs, idioms, anecdotes, pictures and videos of the community for affective value. 
B. Social Media in Teaching-Learning-Process (TLP)

\begin{tabular}{|l|l|l|l|l|l|l|l|l|l|l|}
\hline Use of social media in TLP in DTU & \multicolumn{2}{l}{$\begin{array}{l}\text { Very } \\
\text { poor }\end{array}$} & \multicolumn{2}{l|}{ Poor } & \multicolumn{2}{l|}{ Not at all } & \multicolumn{2}{l|}{ Good } & \multicolumn{2}{l|}{ Excellent } \\
\cline { 4 - 12 } & F & $\%$ & F & $\%$ & F & $\%$ & F & $\%$ & F & $\%$ \\
\hline $\begin{array}{l}\text { Social media for classroom learning } \\
\text { environments or as learning tools }\end{array}$ & 72 & 25.3 & 108 & 37.9 & 73 & 25.6 & 28 & 9.8 & 4 & 1.4 \\
\hline $\begin{array}{l}\text { Social media network accessibility in learning } \\
\text { process }\end{array}$ & 67 & 23.5 & 100 & 35.1 & 87 & 30.5 & 31 & 10.9 & - & -- \\
$\begin{array}{l}\text { Effective use of social media in teaching } \\
\text { learning }\end{array}$ & 68 & 23.9 & 85 & 29.8 & 97 & 34 & 30 & 10.5 & 5 & 1.8 \\
\hline $\begin{array}{l}\text { Access of computer and other technologies to } \\
\text { use social networks in the campus }\end{array}$ & 63 & 22.1 & 82 & 28.8 & 51 & 17.9 & 83 & 29.1 & 6 & 2.1 \\
\hline $\begin{array}{l}\text { Usage of social media in your education: } \\
\text { resource, assignment, and research }\end{array}$ & 31 & 10.9 & 72 & 25.3 & 48 & 16.8 & 99 & 34.7 & 35 & 12.3 \\
\hline
\end{tabular}

Table 9: Respondants' Social Media usage in Teaching-Learning-Process

As stated above, students were asked to rate their use of social media for educational environments as learning tools in DTU, so $63.2 \%$ of them rated that poor and very poor, $25.6 \%$ of them also replied that they did not use social media at all, and $11.2 \%$ of them rate good and excellent.

Accordingly, $58.6 \%$ of the respondents confrimed that social media network accessibility in teaching-learning process (TLP) in DTU were poor and very poor while $30.5 \%$ of them also believed that there is no social media network accessibility for learning process; however, $10.9 \%$ of them rate well. Whereas $53.7 \%$ of the respondents confirmed, there was poor and very poor the use of social media in DTU for TLP. $34 \%$ of them also confirmed that there were no any functionalities of social media usage for TLP while $12.3 \%$ of them rated as good.

$50.9 \%$ of the respondents replied that the access of computer and other technologies to use social networks in the campus is poor and very poor, $31.2 \%$ of them rate as a good, and $17.9 \%$ of them rated not at all.

Respondents were asked about usage of social media in their education; resource, assignment and research, and they rated as good (47\%), poor (36.2\%), and not at all (16.8\%).

The emergence of social media has impacted siginificantly how students learn and the way instructors teach. Social media, especially Facebook can positively affect classroom practices and students involvement (Aydin, 2012). Now a days, social media play its great and enormous role in teaching learning process. Here in DTU, most of students use Facebook for their daily information and educational consuptions. So, Facebook could provide a platform for students to freely share their feelings and ideas on how to improve their communication skills and educational capacity. Social media have great contribution for formal and informal education.

As Roblyer [et-al] (2010) stated that higher education teaching practices emphasis on student-center pedagogy. So, when the student uses social media as teaching tools, they interact, discuss, and make dicscion across their campus and they will express their feeling without any hesitation. Fusch (2011)also assured that social media tools are importance for learning objectives, and that tools are needed which promote social presence, create a more interactive learning enviroment and foster collaborative study. Here, in higher educational institutions technology have great importance for educational facility. It also supports the teaching-learning system and develop the implimanatation of different teaching methods. Dunn (2012) realises that more emphsis must be placed on learnig with technoloy.

Social media have the potential to fundamentally change the charater of our social lives both on interpersonal and community level (Boruah T.D, 2012). However DTU didn't use social media efeectively for TLP. Students should be encoraged to extend its use beyond socialisation to networking and find another opportunities in the global village, rather than block them or discourage social media for communication and education. Because social media has been shown to be vital tool for communication and education. conversely, most of the students have smart phone to use social networks, but the computers which puts in the liberary and laboratory haven't any internet acess. Actve learning and deep interaction between students and their teachers requires an extended degree of technology engagement, Laird and Kuh (2005).

Among social media Facebook and twitter play enormous role for education. As Kent (2014) stated Facebook is being integrated into educational design, including part of formal assessment. Students may be asked to share resources, annotate material online, critic/review related material; or simply comment on the material raised during a unit. Facebook creates potential communication space where teachers and students both take responsibility for the way that they communicate.

Social media is a powerful tool to use in professional context. The interactive nature of the medium can be highly benificial for scientistes by offfrning news perspective on research through dialogue with peers, and helping to establish new collaboration. And also these medium have a great opportunities in education because they are flexiable, repeatable, and convenience and accessablity (Ashraf J. 2012). Most of the scholars aruged that communicating science through social media can help to improve essential scholarly skills such as refelicting, 
writing for different audiences and developing self-discipline to write regularly.

Some of the students use social media in their education as a resource tools for assignment and research. Here, Facebook is a valuable tool in educational communications and collaborations (Magogwe et-al, 2015). It is now use for student interactions, knowledge transfer, and communication, social and cognitive and critical thinking development. As Anne Osterrieder (2013) stated, understanding social media and having the knowledge and confident to use it appropriately and effectively for professional purposes will become essential skills to be included in a scientist's skills tool kit.

\section{Conclusions and Recommendations 6.1. Conclusions}

Social media have affected the modern society positively and have changed some of people's communicating and teaching style especially in higher educational institutions. Social media become digitally literate rather than avoiding resisting its use at all because our communication and education system have been supported by technology. Effective use of features and opportunities of social media in supports instructors' empowering of the educational process with active learning, creativity, problem-solving, cooperation, and multifaceted interactions as well as students' using and improving their academic performance, inquiry, and alternative thinking skills.

Most of undergraduate DTU students have social media profile and they are experienced how they use it especially Facebook, Youtube and twitter. Even if the network was poor, they try to visited the social media site in a day and communicate with their friends, family and relatives with their ages. They have good perceptions about social media and preferences. They also have an interest to use the media as teaching tools; problem solving, discussion, individual learning, research, guided discovery, collaborative work, demonstration and case studies respectively.

The findings indicated that they used it to posting photographs and information, viewing posted photographs, reading information and comments that posted, and it helps them keeping in touch with their family and friends. It has a significant role for communication and socialization in most of the students; however, they believe that it has high negative effects in their academic performance. This platform communication also gives freedom for their daily interaction and utilities.

Even if social media provide opportunities for the academicians, the institutions as well as the instructors didn't use effectively in the teaching learning process. A little bit, the students use social media to learn human values because they are flexible and user friendly to learn such values. Accordingly, the findings revealed that social media have many benefits for education: it increases students motivation and engagement with course modules, it increases student to student collaboration, it accelerate data and information sharing, it enhanced interaction between the students and the lecturers, it provides students with $21^{\text {st }}$ century skills, and increase level of satisfaction.

Therefore, this study doesn't attempt to generalize its findings but to inform future studies and discussions on the use of social media in Ethiopian higher educational institutions.

\subsection{Recommendations}

After a detailed investigation of the use of social media in Debre Tabor University particularly in undergraduate student's social media usage, the researchers forwarded the following suggestions for a social media strategy for Communication and Education.

- Debre Tabor University is "New and Different", so it will better to use social media to engage with its audience well versed in new media channels. Social media is seen as a various tool for university communicators due to its low cost, immediacy, and its heterogeneous audience.

- If social media has been implemented in DTU as teaching methods, it will serve to the lectures distribute course guidebook, modules, notes and other course information in soft copy.

- Students' participation and collaboration will be greatly increased when social media platforms are integrated with the learning program. Active learning method will be easy to implement in the class room, and also cooperative learning will be support by technology. It will provide chat forum where students can communicate with their lecturers, and with each other, and the students will get active advice with their advisers.

- We can use social media for academic purpose that will support by technology for knowledge and experience sharing. Thus, DTU should develop network usage strategy and implementation that helps the instructors and students social media users. This environment enables the university to give distance courses by social media. However that the first perceptions should be changed.

- In addition, by using different communication levels; top-down and bottom-up approaches should be continuously provide training opportunities for volunteers through e-Learning, everybody can be armed with the necessary information and skills. This helps the institution to empower the community by giving continuous training for human development. 
- $\quad$ Beside to these, DTU prepared different symposium in collaboration with different institutions, so it should be a systematic approach to support symposiums, conferences etc. to form databases and increase collaboration.

- It is also important for administrative workers enable them to use social media effectively for communication and education. Social media assure participatory communication in the organization. The administrative staffs also will use it to upgrade their skills and knowledge.

\section{Acknowledgement}

We would like to thank in heart our respondents, DTU 2017 graduate class students and the people that contribute for the accomplishment of this work i.e. Hailu Minale, Director of Guna Tana Integrated Field Research Center, Efirem Jarsa'a, Melat Hailu, and Department heads.

\section{References}

Aditi Grover and David W. Steward. (2010). Defining Interactive Social Media in an Educational Context, Cutting-Edge Social Media Approaches to Business Education, Information Age Publishing.

Ali, A. H. (2011). The Power of social media in developing nations: New tools for closing the global digital divide and beyond. Harvard Human Rights Journal, 24(1).

Ashraf J. (2012). Use of Social Networking in Education: Challenges and opportunities. (Vol-2 No.1,18,21,2012) Aydin, S. (2012). A review of research on Facebook as an educational environment. http://dx.doi.org/10.1007/s11423-012-9260- 7 Balakri.

Baker, L. R., \& Oswald, D. L. (2010). Shyness and online social networking services. Journal of Social \& Personal Relationships, 27(7), 873-889. doi:10.1177/0265407510375261

Baruah D.T. (2012) Effectiveness of Social Media as a tool of communication and its potential for technology enabled connections: Guwahati-781006, Assam, India: International Journal of Scientific and Research Publications, Volume 2, Issue 5, May 20121 ISSN 2250-3153

Blumler, J. G. (1979). The role of theory in uses and gratifications studies. Communication Research 6. doi:10.1177/009365027900600102.

Blumler, J. G., \& Katz, E. (1974). The uses of mass communications: Current perspectives on gratifications research. Beverly Hills, Calif.: Sage.

Boyd, d. (2014). The social lives of networked teens. New Haven; London: Yale University Press.

Boyd, D. M., \& Ellison, N. B. (2008). Social network sites: Definition, history, and scholarship. Journal of Computer-Mediated Communication, 13.

Cavazza, F. (2008). "Social Media Landscape." Retrieved July 30, 2008, from: http://flickr.com/photos/20493464@N00/2564571564/

Clark, L. S. (2013). The Parent App. Oxford: Oxford University Press

Drussell J. (2012). Social Networking and Interpersonal Communication and Conflict Resolution Skills among College Freshmen: http://sophia.stkate.edu/msw papers/21

Dunn, L. (2012) Why It's Time to Start BOYD in Your School on Edudemic. http://edudemic.com/2012/ (and also accessed in 2013).

Fusch, D. (2011) Social Media and Student Learning: Moving the needle on engagement in Academic Impressions: http://www.fredcavazza.net/2008/06/09/social-media-landscape/

Gouseti A. (2010). Web 2.0 and Education: Not Just Another Case of Hype, Hope and Disappointment? Learning, Media and Technology.

Grabarczyk-Tokaj M. (2013). Implementation of analyses based on social media data for marketing purposes in academic and scientific organizations in practice-opportunities and limitations. Warsaw, Poland: file://C:/Users/www/Downloads/Grabarczyk-Tokaj_Implementation-of-analyses-based-on-social-mediadata-for-marketing-purposes-in-academic-and-scientific-organizations\%20(3).pdf

Ito, M. (2010). Hanging out, messing around, and geeking out: kids living and learning with new media. Cambridge, Mass: MIT Press.

Joinson, A. N. (2008). "Looking at", "Looking up" or "Keeping up with" people? Motives and uses of Facebook. Proceedings of CHI. New York: ACM. doi:10.1145/1357054.1357213

Kaplan, A., \& Haenlin, M. (2010). "Users of the world, unite! The challenges and opportunities of Social Media." Business Horizons, 53(1).

Katz, E., Blumler, J.G., \& Gurevitch, M. (1974). “Uses and Gratification Research.” Public Opinion Quarterly, Vol. 37, No. 4, pp. 509-523.

Kavitha S.(2015). The Ethiopian Herald. Addis Abeba.

Kelleher, T., \& Sweetser, K. (2012). Social media adoption among university communicators. Journal of Public Relations Research, 24(2). 
Kent M. (2014). What's on your mind? Facebook as a forum for teaching and learning in higher education. An education in Facebook: Higher education and the World's largest social network. New York. Routledge.

Laird, T and Kuh, G. (2005) Student Experiences with information technology and their relationships to other aspects of student engagement in Research in Higher Education 46 (2): pp. 211-3.

Lula Tewfik. (2007). An Exploratory Study of Internet Use for Education and Research by Postgraduates in AAU.

Maggiani, R. (2014). Social media and its effect on communication: multidimensional interactions have altered the basic rules of communication: www.solari.net/documents/position-papers/Solari-Social-Media-andCommunication.pdf

Magogwe, J.M., Ntereke, B. \& Phetlhe, K.R. (2015). Facebook and classroom group work: A trial study involving University of Botswana Advanced Oral Presentation students. British Journal of Educational Technology, 46(6), 1312-1323. Wiley. Retrieved September 29, 2017 from: https://www.learntechlib.org/p/151949/.

MaQuail D. (1983). McQuail's Mass Communication Theory, $6^{\text {th }}$ ed. SAGE Publications Asia-Pacific Pte.Ltd.

Mayfield, A. (2008). What is Social http://www.icrossing.co.uk/fileadmin/uploads/eBooks/What_is_Social_Media_iCrossing_ebook.pdf

Osborne N. (2011). Best Practice for Social Media in Teaching \& Learning Contexts: https://www.slideshare.net/edinadocumentationofficer/best-practice-for-social-media-in-teaching-learningcontexts-nicola-osborne

Osterrieder A. (2013). The value and use of social media as communication tool in the plant sciences:http:/www.plantcellbiology.com/2013/02/connect-with-plant-scientists-on-social-networkingsites/.

Papacharissi, Z. (2010). A networked self. London, Routledge.

Pempek, T. A., Yermolayeva, Y. A., \& Calvert, S. L. (2009). College students' social networking experiences on facebook. Journal of Applied Developmental Psychology, 30(3). doi:10.1016/j.appdev.2008.12.010

Quan-Haase, A., \& Young, A. L. (2010). Uses and gratifications of social media: A comparison of facebook and instant messaging. Bulletin of Science, Technology \& Society, 30(5). doi:10.1177/0270467610380009

Redecker, C., Ala-Mutka, K. and Punie, Y. (2010) Learning 2.0 - The Impact of Social Media on Learning in Europe, JRC Scientific and Technical Report, http://www.ict-21.ch/com-ict/IMG/pdf/learning-2.0-EU17pages-JRC56958.pd

Roblyer, M.D, McDaniel, M, Webb, M, Herman, J and Witty, J. (2010). Findings on Facebook in higher education: A comparison of college faculty and student uses and perceptions of social networking sites in Internet and Higher Education, Elesvier.

Ruggiero, T. E. (2000). Uses and gratifications theory in the 21 st century. Mass Communication \& Society, 3(1).

Selwyn N. (2012) Social media in formal and informal education between potentialities and reality: http://dx.doi.org/10.17471/2499-4324/174

Selwyn N. (2012). SOCIAL MEDIA IN HIGHER EDUCATION. www.worldoflearning.com.

Solis, B. (2008). "Introducing the Coversation Prism." Retrieved August 6, 2008, from: http://www.briansolis.com/2008/08/introducing-conversationprism.html.

Solis, B. (2008). Customer Service: The Art of Listening and Engagement through Social Media: 32.

Solis, B. (2008). The Essential Guide to Social Media.

Tapscott, D. \& A. D. Williams. (2007). Wikinomics: How Mass Collaboration Changes Everything. New York: Penguin.

Tapscotte J, Chris and Shao, Binhui (2011). The net generation and digital natives: implications for higher education. Higher Education Academy, York.

Tufekci, Z. (2008). Grooming, gossip, facebook, and myspace. Information, Communication \& Society, 11(4). doi:10.1080/13691180801999050.

Walther, J. B. (1992). Interpersonal effects in computer-mediated interaction: A relational perspective. Communication Research, 19.

http://connection.ebscohost.com/c/articles/74485990/social-networking-online-privacy-facebook-usersperceptions

http://kavithaseoexpert.blogspot.in/

http://www.nyc.gov/html/sbs/nycbiz/downloads/pdf/educational/small\%20business\%20digital\%20toolkit/NYCB usinessSolutions_best_practices_for_social_media.pdf

https://cit.duke.edu/blog/2012/04/six-ways-to-use-social-media-in-education/ 